\title{
Efektivitas Terapi Kortikosteroid Intranasal pada Hipertrofi Adenoid Usia Dewasa berdasarkan Pemeriksaan Narrow Band Imaging
}

\author{
Sinta Sari Ratunanda, Jipie Iman Satriyo, Dindy Samiadi, Teti Madiadipoera, Ratna Anggraeni \\ Departemen Ilmu Kesehatan Telinga Hidung Tenggorok-Bedah Kepala Leher \\ Fakultas Kedokteran Universitas Padjadjaran/Rumah Sakit Dr. Hasan Sadikin Bandung
}

\begin{abstract}
Abstrak
Hipertrofi adenoid merupakan proses perubahan ukuran adenoid yang membesar, merupakan penyebab utama hidung tersumbat. Hipertrofi adenoid dapat terjadi karena proses yang fisiologis, akibat inflamasi, atau suatu keganasan. Proses inflamasi adenoid dapat dinilai menggunakan nasoendoskopi serat lentur dengan pencahayaan narrow band imaging (NBI). Kortikosteroid intranasal menjadi pilihan terapi medikamentosa pada penatalaksanaan hipertrofi adenoid pada anak, namun belum banyak diteliti penggunaannya pada hipertrofi adenoid usia dewasa. Tujuan penelitian ini menilai efektivitas terapi kortikosteroid intranasal untuk mengurangi ukuran adenoid dewasa berdasarkan pemeriksaan NBI. Penelitian dimulai bulan November 2012-Januari 2013 di poliklinik Telinga Hidung Tenggorok-Bedah Kepala Leher Rumah Sakit Dr. Hasan Sadikin (THT-KL RSHS) Bandung dengan metode kuasieksperimental open labeled pre and posttest design. Pemilihan sampel berdasarkan urutan kedatangan, ditentukan 11 subjek penelitian. Penegakan diagnosis pada subjek penelitian berdasarkan anamnesis, pemeriksaan fisis THT, pemeriksaan nasoendoskopi serat lentur dilengkapi dengan NBI, dan dilakukan biopsi mukosa adenoid. Subjek penelitian diberikan terapi kortikosteroid intranasal selama empat minggu, kemudian dilakukan evaluasi ulang pemeriksaan NBI dan biopsi. Data dianalisis dengan uji Wilcoxon, hasilnya didapatkan perbaikan nilai derajat inflamasi adenoid secara signifikan pascaterapi kortikosteroid intranasal $(\mathrm{p}<0,05)$. Uji McNemar didapatkan hasil signifikan untuk penurunan ukuran adenoid $(\mathrm{p}<0,05)$. Uji rank Spearman untuk menganalisis hubungan gambaran histopatologi dengan penilaian NBI pra dan pascaterapi, hasilnya didapatkan korelasi bermakna $(\mathrm{p}<0,05)$. Simpulan, kortikosteroid intranasal efektif diberikan pada inflamasi penyebab hipertrofi adenoid usia dewasa berdasarkan pemeriksaan NBI. [MKB. 2016;48(4):228-33]
\end{abstract}

Kata kunci: Hipertrofi adenoid, kortikosteroid intranasal, narrow band imaging

\section{Effectiveness of Intranasal Corticosteroids Treatment on Adult Adenoid Hypertrophy based on Narrow Band Imaging Examination}

\begin{abstract}
Adenoid hypertrophy is a process in which adenoid size becomes enlarged and causes clinical symptoms, especially nasal obstruction. Adenoid hypertrophy can be due to physiological, inflammatory, or malignancy processes. Adenoid inflammatory process can be assessed using a flexible fiberoptic nasoendoscopy with narrow band imaging (NBI). Intranasal corticosteroid is one of the choices to treat adenoid hypertrophy in children; however, more experiments are needed to use it in adults. This study was performed in the period of November 2012 to January 2013 at the outpatient clinic of the Otorhinolaryngology-Head and Neck Surgery Department of Dr. Hasan Sadikin General Hospital Bandung, using pre- and post-test open-labeled quasiexperimental design. Sample was selected through consecutive sampling, involving 11 subjects. Diagnosis was based on research subject's anamnesis, ear nose and throat (ENT) physical examination, NBI-equipped fiberoptic nasoendocopy examination, and adenoid mucosal biopsy. Subjects were given intranasal corticosteroid therapy for four weeks. NBI-equipped fiberoptic nasoendocopy examination and biopsy examination were performed after therapy. Data were analyzed using Wilcoxon test, showing significant improvement of the adenoid inflammation after intranasal corticosteroids therapy $(\mathrm{p}<0.05)$. McNemar test results showed a significant reduction in adenoid size $(\mathrm{p}<0.05)$. Spearman rank test showed a significant correlation between histopathologic findings and NBI examination result $(\mathrm{p}<0.05)$. In conclusion, intranasal corticosteroids are effective for adult adenoid hypertrophy treatment based on NBI examination. [MKB. 2016;48(4):228-33]
\end{abstract}

Key words: Adenoid hypertrophy, intranasal corticosteroids, narrow band imaging

Korespondensi: Sinta Sari Ratunanda, dr., M.Kes, Sp.THT-KL, Departemen Ilmu Kesehatan THT-KL Fakultas Kedokteran Universitas Padjadjaran/Rumah Sakit Dr. Hasan Sadikin Bandung, Jalan Pasteur No. 38 Bandung, mobile 08122013576, e-mail sonson_tht@yahoo.com 


\section{Pendahuluan}

Adenoid adalah jaringan limfoid berlobus ditemukan pada dinding atas dan belakang nasofaring yang dapat meluas ke fosa rosenmuler dan muara tuba eustakius. Adenoid mempunyai fungsi dalam proses imunologis sejak lahir yang memiliki peran untuk proteksi di permukaannya terutama dari virus dan bakteri patogen dengan cara menyekresikan imunoglobulin A (IgA). Secara fisiologis ukuran adenoid mengalami hipertrofi pada masa puncaknya, yaitu usia 6-7 tahun akan mengecil pada usia 6-16 tahun. ${ }^{1}$

Di dalam beberapa penelitian hipertrofi adenoid dapat ditemukan pada usia dewasa. Hamdan dkk. $^{2}$ menyatakan dari pasien yang datang dengan keluhan hidung tersumbat, 63,6\% ditemukan hipertrofi adenoid, seluruhnya menderita alergi dan secara signifikan ditandai sekret purulen. Yildirim dkk. $^{3}$ menemukan 40 pasien usia dewasa dengan hipertrofi adenoid dalam rentang waktu lima tahun. Mitchell dkk. ${ }^{4}$ melaporkan 110 sampel yang dikumpulkan selama 4 tahun, kemudian dilakukan penilaian secara patologi anatomi, hasilnya 92 sampel (84\%) merupakan proses inflamasi dan 18 sampel (16\%) diduga sebagai proses keganasan. Di Departemen Telinga Hidung TenggorokKepala Leher Rumah Sakit Dr. Hasan Sadikin (THT-KL RSHS) Bandung periode JanuariDesember 2011 berdasarkan hasil pemeriksaan endoskopi kaku ditemukan 56 pasien usia dewasa dengan hipertrofi adenoid. ${ }^{5}$

Brodsky dan Poje $^{1}$ menjelaskan etiologi hipertrofi adenoid belumlah dapat dibuktikan secara jelas, namun dapat disimpulkan, yaitu secara fisiologis, faktor inflamasi, serta proses keganasan. Hipertrofi adenoid secara fisiologis umumnya bersifat asimtomatik, gejala klinis akan timbul jika ukuran pembesaran mengisi dua per tiga rongga nasofaring. Inflamasi adenoid ditandai dengan ditemukan pembesaran ukuran adenoid atau hipertrofi adenoid. Umumnya hipertrofi adenoid ditemukan dengan gejala klinis berupa hidung tersumbat, rhinolalia, dapat terjadi perubahan bernapas lewat mulut, serta sering pula disertai mengorok sehingga menyebabkan gangguan napas pada saat tidur, peradangan telinga tengah, dan sinusitis.

Faktor inflamasi adenoid dapat terjadi akibat infeksi saluran napas atas berulang, iritasi dari asap rokok, gangguan pertahanan tubuh, refluks laringofaring, serta yang paling sering akibat alergi. ${ }^{2}$ Pada pasien alergi ditemukan peningkatan IgE pada mukosa adenoid dan juga peningkatan interleukin 1(IL-1) IL-4, IL-5, IL-6, IL-8, tumor necroting factor $\alpha$ (TNF- $\alpha$ ) serta interferon- $\gamma$ (INF- $\gamma$ ) sebagai mediator proinflamasi. ${ }^{2}$ Hal ini diperkuat dengan beberapa penelitian yang menyatakan bahwa pada penderita inflamasi adenoid dengan hipertrofi adenoid ditemukan hasil skin prick test (SPT) positif. ${ }^{1,3}$

Pembesaran adenoid tersebut dapat dicurigai suatu proses keganasan apabila dalam gambaran makroskopis berbenjol, rapuh, dan juga mudah berdarah. Mitchel dkk. ${ }^{4}$ telah melakukan biopsi pada pasien hipertrofi adenoid dewasa dengan temuan merupakan karsinoma sel skuamosa, differentiated non-keratinizing carcinoma, undifferentiated non-keratinizing carcinoma, dan limfoma.

Pemeriksaan patologi anatomi dapat menilai struktur histopatologi mukosa adenoid sehingga dari hasil biopsi dapat ditentukan kelainan yang terjadi di permukaan adenoid tersebut merupakan suatu proses dari keganasan atau inflamasi. Derajat inflamasi dapat ditentukan dengan membuktikan hiperplasia limfoid pada gambaran mikroskopis tersebut. Wang dkk. $^{6}$ dalam penelitiannya telah mengemukakan hasil histopatologi berupa hiperplasia adenoid.

Pemeriksaan untuk menegakkan diagnosis hipertrofi adenoid dapat dilaksanakan dengan pemeriksaan rinoskopi posterior, foto polos jaringan dari lunak leher, pencitraan magnetic resonance imaging (MRI), dan juga pemeriksaan nasoendoskopi. Penggunaan pencitraan MRI pada adenoid dapat dilakukan untuk menilai ukuran pembesaran adenoid. Pemeriksaan itu menggunakan endoskopi saat ini merupakan pemeriksaan baku emas untuk menilai ukuran pembesaran pada adenoid. ${ }^{7}$ Seiring dengan perkembangan teknologi pada saat ini, keadaan patologis adenoid pada dewasa dapat dinilai menggunakan alat nasoendoskopi serat lentur dengan pencahayaan yang khusus, yaitu narrow band imaging (NBI). ${ }^{8}$ Metode pemeriksaan ini menggunakan alat ini mempunyai keunggulan, yaitu dapat melihat jenis pembesaran adenoid ini suatu gambaran proses keganasan atau inflamasi. Secara sederhana alat NBI ini bekerja berdasarkan pemakaian panjang gelombang kelompok cahaya tertentu yang mengakibatkan perbedaan penyerapan cahaya oleh pembuluh darah dan jaringan sekitarnya. ${ }^{9}$ Wang dkk. ${ }^{6}$ telah melaksanakan penelitian menggunakan NBI pada hipertrofi adenoid usia dewasa dan hasil gambaran NBI itu dihubungkan dengan pemeriksaan patologi anatomi. Dari penelitian tersebut disimpulkan bahwa alat NBI memiliki sensitivitas $92,1 \%$ dan spesifisitas $95,1 \%$. Hal ini menjadi dasar pemeriksaan awal untuk menilai 
keadaan adenoid sehingga dapat membantu mempertegas lokasi biopsi. ${ }^{6}$

Penatalaksanaan inflamasi adenoid tersebut dapat berupa medikamentosa atau tindakan secaraoperatif. Penatalaksanaan medikamentosa adalah pemberian kortikosteroid intranasal, kortikosteroid per oral, obat antimikrob, dan proton pump inhibitor (PPI), serta antihistamin. Kortikosteroid intranasal dapat mengurangi proses inflamasi adenoid melalui mekanismenya menekan produksi sitokin, sel mast, basofil, mencegah perubahan, sintesis IgE oleh sel B, menurunkan migrasi sel inflamasi, menekan tahapan ekspresi granulocyte macrophage colony stimulating factor (GM-CSF), IL-6, IL-8, regulated on activation normal $t$-cell expresed and secreted (RANTES), kemokin, penurunan jumlah sel epitel cluster of diferentiation 3 (CD3), CD4+, CD8+, CD25+ dan IL-4. ${ }^{10}$ Chandka dkk. ${ }^{11}$ telah melaporkan hasil meta-analisis dari beberapa penelitian lalu bahwa pemberian kortikosteroid intranasal pada pasien anak efektif untuk dapat mengurangi gejala hipertrofi adenoid, keadaan ini perlu dibuktikan pada kelompok usia dewasa guna mencari metode pengobatan yang lebih baik. Hingga saat ini masih jarang penelitian mengenai efektivitas kortikosteroid intranasal yang diberikan pada inflamasi adenoid usia dewasa.

Apabila terapi medikamentosa tersebut tidak mendapatkan hasil yang maksimal maka dilaksanakan tindakan operatif adenoidektomi. Tindakan operatif ialah menjadi pilihan terakhir karena memiliki faktor risiko, komplikasi, dan juga kontraindikasi yang perlu dipertimbangkan, serta efek samping yang berat. Tujuan penelitian ini mengetahui efektivitas terapi kortikosteroid intranasal untuk mengurangi ukuran adenoid dewasa berdasarkan pemeriksaan NBI.

\section{Metode}

Metode penelitian berjenis kuasi eksperimental open label pretest and postest design. Penelitian dilakukan pada pasien yang datang ke poliklinik THT-KL RSHS sesuai urutan kedatangan dan juga memenuhi kriteria inklusi. Setelah pasien mendapatkan informasi yang lengkap mengenai prosedur penelitian yang akan dilaksanakan, selanjutnya apabila pasien setuju dilakukan penandatanganan surat bersedia keikutsertaaan (informed consent) dalam penelitian.

Semua penderita yang termasuk subjek penelitian dilakukan pemeriksaan fisis THT, juga pemeriksaan nasoendoskopi serat lentur mempergunakan pencahayaan NBI lalu dinilai derajat inflamasi, dan dilakukan biopsi. Untuk mencegah infeksi sekunder pascabiopsi, pasien diberikan antibiotik selama 3 hari. Sampel penelitian diberi terapi kortikosteroid intranasal sebanyak 2 x50 $\mu \mathrm{g}$ pada setiap lubang hidung selama empat minggu. Setelah pemberian kortikosteroid intranasal dilakukan evaluasi ulang menggunakan nasoendoskopi serat lentur yang dilengkapi pencahayaan NBI dan biopsi untuk dapat penilaian efektivitas kortikosteroid intranasal. Pemeriksaan secara histopatologi dilakukan dalam penelitian ini sebagai prosedur pemeriksaan baku emas untuk dapat menilai inflamasi adenoid. Pengujian dilakukan untuk membedakan derajat inflamasi adenoid sebelum dengan setelah diberikan terapi kortikosteroid intranasal. Uji Wilcoxon digunakan sebab data tidak berdistribusi normal. Untuk dapat menilai korelasi antara efektivitas terapi kortikosteroid berdasarkan pemeriksaan histopatologi dan NBI menggunakan uji rank Spearman. Kemaknaan hasil uji ditentukan berdasarkan nilai $\mathrm{p} \leq 0,05$.

Pada penelitian ini dilakukan pemeriksaan SPT untuk menegakkan predisposisi dari rinitis alergi, bila hasilnya positif maka didiagnosis memiliki predisposisi rinitis alergi. Penilaian skor gejala refluks (SGR) dan skor temuan refluks (STR) dilakukan untuk menegakkan predisposisi refluks laringofaring. Apabila ditemukan SGR $>13$ dan STR $\geq 7$ maka didiagnosis memiliki predisposisi refluks laringofaring.

Nasoendoskopi yang dilengkapi pencahayaan NBI dapat memprediksi pembesaran adenoid tersebut apakah suatu proses inflamasi atau suatu keganasan. Derajat inflamasi dapat dinilai

Tabel 1 Karakteristik Subjek

\begin{tabular}{cc}
\hline Karakteristik & Jumlah \\
\hline Jenis kelamin & 7 \\
Pria & 4 \\
Wanita & \\
Usia (tahun) & 4 \\
$14-19$ & 6 \\
$20-29$ & 1 \\
$30-39$ & 0 \\
$40-49$ & 0 \\
$>50$ & 21,64 \\
Rata-rata & 20 \\
Median & $14-55$ \\
Rentang &
\end{tabular}


menggunakan NBI dengan melihat pola garis putih yang tampak pada permukaan adenoid. Dilakukan pemeriksaan NBI praterapi dan pascaterapi pemberian kortikosteroid intranasal selama empat minggu.

\section{Hasil}

Besar sampel pada penelitian ini sebelas orang berdasarkan atas rumus besar sampel yang ditentukan dengan taraf kepercayaan 95\% dan power test $90 \%$. Dilakukan karakteristik subjek berdasarkan jenis kelamin dan rentang usia. Dari 11 subjek penelitian didapatkan lebih banyak pria dibanding dengan wanita, terbanyak pada kelompok usia 20-29 tahun, didapatkan ratarata 21,64 tahun.

Etiologi hipertrofi adenoid saat ini masih belumlah ditemukan, namun beberapa faktor predisposisi dapat berperan pada terjadinya inflamasi adenoid pada kelompok usia dewasa. Faktor predisposisi tersebut antara lain rinitis alergi dan refluks laringofaring.

Pada penelitian ini ternyata didapatkan bahwa faktor predisposisi hipertrofi adenoid usia dewasa adalah refluks laringofaring dan rinitis alergi. Refluks laringofaring merupakan faktor predisposisi pada 8 dari 11 subjek yang ditemukan dalam penelitian ini.

Hipertrofi adenoid itu menjadi gambaran klinis untuk menegakkan inflamasi adenoid. Ukuran adenoid diukur berdasarkan temuan nasofaringoskopi serat lentur tanpa pencahayaan NBI. Ukuran adenoid menetap pada seorang dan 10 orang mengecil. Secara statistik perubahan ukuran tersebut dari 90,1\% menjadi 10,1\%, hasil ini sangat bermakna dengan nilai $\mathrm{p}=0,004$.

Berdasarkan uji statistik Wilcoxon tersebut didapatkan perbedaan sangat bermakna derajat inflamasi adenoid praterapi dengan pascaterapi berdasarkan pemeriksaan NBI $(p=0,005)$.

Gambaran histopatologi hipertrofi adenoid dalam penelitian ini seluruhnya menunjukan hiperplasia limfoid, tidak ada yang menunjukkan gambaran keganasan. Berdasarkan perhitungan statistik menggunakan uji Wilcoxon didapatkan perbedaan sangat bermakna $(p=0,004)$ pada
Tabel 2 Faktor Predisposisi Hipertrofi Adenoid

\begin{tabular}{lc}
\hline \multicolumn{1}{c}{ Faktor Predisposisi } & Jumlah \\
\hline Rinitis alergi & 3 \\
Refluks laringofaring & 4 \\
Refluks laringofaring dan & 4 \\
Rinitis alergi & \\
\hline
\end{tabular}

derajat inflamasi berdasarkan atas pemeriksaan histopatologi antara praterapi dan pascaterapi kortikosteroid intranasal (Tabel 4).

Berdasarkan analisis statisitik dengan uji rank Spearman didapatkan hubungan bermakna $(p=0,003)$ antara pemeriksaan histopatologi dan NBI.

\section{Pembahasan}

Inflamasi adenoid pada kelompok usia dewasa ditandai dengan hipertrofi adenoid. Angka prevalensi hipertrofi adenoid usia dewasa pada penelitian di India adalah 9\% dengan perbandingan lebih banyak pria daripada wanita kelompok usia terbanyak 6-25 tahun. ${ }^{12}$ Penelitian lain di Beirut menyatakan hipertropi adenoid usia dewasa distribusi terbanyak pada pria sekitar 54\% serta terjadi pada kelompok usia 17-43 tahun sekitar $60 \%{ }^{3}$ Pada penelitian ini didapatkan prevalensi $6 \%$ dari seluruh pasien di tempat penelitian, lebih sering terjadi pada pria dan pada kelompok usia 20-29 tahun.

Faktor predisposisi hipertrofi adenoid pada usia dewasa sangat bervariasi. Pada penelitian di India ditemukan 9 dari 11 orang menderita rinitis alergi..$^{12}$ Penelitian lainnya oleh Yildirim dkk. ${ }^{3}$ di Turki ditemukan 6 dari 11 orang memiliki faktor predisposisi berupa rinitis alergi. Pada penelitian ini ditemukan predisposisi berupa rinitis alergi sebesar 5 dari 11 orang. Faktor predisposisi lain yang diteliti adalah refluks laringofaring sebanyak 9 dari 11 orang sehingga refluks laringofaring menjadi predisposisi yang paling banyak. Ditemukan perbaikan derajat inflamasi berdasarkan pemeriksaan NBI pada

Tabel 3 Perbaikan Ukuran Adenoid Praterapi dan Pascaterapi Kortikosteroid Intranasal Selama 4 Minggu

\begin{tabular}{cccc}
\hline Ukuran Adenoid & Praterapi & Pascaterapi & p \\
\hline$<50 \%$ & 1 & 10 & 0,004 \\
$51-75 \%$ & 10 & 1 & 104 \\
\hline
\end{tabular}


Tabel 4 Perbaikan Derajat Inflamasi Adenoid

\begin{tabular}{ccccc}
\hline Derajat Inflamasi & Praterapi & Pascaterapi & $\mathbf{Z}_{\mathrm{w}}$ & $\mathbf{p}$ \\
\hline NBI & 1 & & & \\
1 & 5 & 3 & & \\
2 & 5 & 0 & & \\
3 & & & & \\
Histopatologi & 0 & 9 & & \\
0 & 7 & 2 & 005 \\
1 & 4 & 0 & 2,845 & 004 \\
\hline
\end{tabular}

Keterangan: $\mathrm{Z}_{\mathrm{w}}=$ uji Wilcoxon; $\mathrm{p} \leq 0,05=$ bermakna

inflamasi adenoid usia dewasa.

Hidung tersumbat adalah merupakan gejala tersering yang timbul akibat hipertrofi adenoid. Kortikosteroid intranasal memiliki kemampuan untuk mengikat reseptor glukokortikoid yang berperan dalam proses inflamasi adenoid. Dalam beberapa penelitian telah terbukti perbaikan ukuran adenoid pascapemberian kortikosteroid intranasal. Berluchi dkk. ${ }^{13}$ dalam penelitiannya membuktikan bahwa penurunan ukuran adenoid hingga $20 \%$ pada 22 pasien anak. Cengel dan Akyol $^{14}$ menjelaskan dalam penelitiannya bahwa ukuran adenoid mengalami perbaikan hingga $50 \%$ pada 45 pasien anak. Pada penelitian ini dilaporkan bahwa ukuran adenoid mengalami perbaikan hingga $40 \%$ dari 10 pasien. Hal ini membuktikan bahwa kortikosteroid intranasal dapat mengurangi ukuran adenoid akibat proses inflamasi.

Modalitas adalah salah satu pemeriksaan, yaitu mempergunakan endoskopi serat lentur dengan bantuan NBI memperlihatkan derajat inflamasi pada lapisan mukosa. Penelitian yang dilakukan oleh Wang dkk. ${ }^{6}$ menyatakan bahwa pemeriksaan mempergunakan endoskopi NBI lebih baik daripada menggunakan pemeriksaan endoskopi konvensional. Pada penelitian ini didapatkan perbaikan mukosa di permukaan adenoid. Dilakukan penilaian derajat inflamasi berdasarkan NBI sebelum dan setelah diberikan terapi kortikosteroid secara intranasal. Hasilnya ditemukan penurunan derajat inflamasi yang yang sangat bermakna sehingga kortikosteroid intranasal dapat menurunkan derajat inflamasi adenoid berdasarkan pemeriksaan NBI.

Pemeriksaan secara histopatologis dilakukan sebagai standar baku emas untuk dapat menilai proses inflamasi yang terjadi. Pada penelitian ini seluruh hasilnya berupa gambaran jinak berupa hiperplasia limfoid, ditandai peningkatan jumlah sel folikel limfoid, jumlah sel musin dan sel goblet, ukuran beberapa sel germinativum ditemukan membesar, dan tidak perubahan struktur mukosa yang merupakan gambaran metaplasia. Yildirim dkk. ${ }^{3}$ melaporkan bahwa pada keadaan hipertrofi adenoid pada usia dewasa menunjukkan sel fibrosis, infiltrasi sel inflamasi kronik, juga ditemukan perubahan struktur mukosa menjadi squamous metaplasia. Tujuan pemberian kortikosteroid intranasal adalah mengurangi jumlah sel folikel limfoid serta mengurangi ukuran sel germinativum. Pada penelitian ini hasilnya didapatkan sangat bermakna. Jumlah sel musin dalam lapang pandang menjadikan indikator derajat inflamasi pada pemeriksaan histopatologi.

Pemeriksaan adenoid mempergunakan NBI merupakan modalitas yang terbaru, terutama keadaan ini dapat diterapkan pada usia dewasa karena pemeriksaan ini dapat membedakan pembesaran adenoid tersebut akibat proses inflamasi atau keganasan. Wang dkk. ${ }^{6}$ telah melakukan penelitian dengan membandingkan hasil histopatologi itu dengan pemeriksaan menggunakan NBI, hasilnya terdapat korelasi yang signifikan. Dalam penelitian ini ditemukan hubungan bermakna derajat inflamasi adenoid menggunakan pemeriksaan secara histopatologi dengan pemeriksaan endoskopi menggunakan pencahayaan NBI.

Simpulan, kortikosteroid intranasal efektif menurunkan derajat inflamasi adenoid pada pasien usia dewasa menggunakan penelaahaan NBI. Keluhan utama hipertrofi adenoid tersering pada usia dewasa berupa hidung tersumbat. Faktor predisposisi hipertrofi adenoid pada usia dewasa dapat ditemukan refluks laringofaringeal dan rinitis alergi. Penggunaan nasoendoskopi 
dilengkapi pencahayaan NBI memiliki korelasi dengan pemeriksaan secara histopatologi untuk menentukan derajat inflamasi pada adenoid.

\section{Daftar Pustaka}

1. Brodsky L, Poje C. Tonsillitis, tonsillectomy and adenoidectomy. Dalam: Bailey BJ, Johnson JT, penyunting. Head \& neck surgeryotolaryngology. Edisi ke-4. Philadelphia: Lippincott Williams \& Wilkins; 2006. hlm. 1183-98.

2. Hamdan AL, Sabra O, Hadi U. Prevalence of adenoid hypertrophy in adults with nasal obstruction. J Otolaryngol Head Neck Surg. 2008;37(4):469-73.

3. Yildirim N, Sahan M, Karslioglu Y. Adenoid hypertrophy in adults: clinical and morphological characteristics. J Int Med Res. 2008;36(1):157-62.

4. Mitchell JE, Pai I, Pitkin L, Moore-Gilon V. A case for biopsying all adult adenoidal tissue. Int J Otorhinolaryngol. 2009;9(2):1-9.

5. Buku kunjungan pasien rekam medik rawat jalan THT-KL RSHS; 2011.

6. Wang WH, Lin YC, Weng HH, Lee KF. Narrowband imaging for diagnosing adenoid hypertrophy in adults: a simplified grading and histologic correlation. Laryngoscope. 2011;121(5):965-70.

7. Saedi B, Sadeghi M, Mojtahed M, Mahboubi H. Diagnostic efficacy of different methods in the assessment of adenoid hypertrophy. Am J Otolaryngol. 2011;32(2):147-51.

8. Piazza C, Dessouky O, Peretti G, Cocco D,
De Benedetto L, Nicolai P. Narrow-band imaging: a new tool for evaluation of head and neck squamous cell carcinomas. Review of the literature. Acta Otorhinolaryngol Ital. 2008;28(2):49-54.

9. Watanabe A, Taniguchi M, Tsujie H, Hosokawa M, Fujita M, Sasaki S. The value of narrow band imaging for early detection of laryngeal cancer. Eur Arch Otorhinolaryngol. 2009;266(7):1017-23.

10. Mygind N, Nielsen LP, Hoffmann HJ, Shukla A, Blumberga G, Dahl R, dkk. Mode of action intranasal corticosteroids. J Allergy Clin Immunol. 2011;108(1 Suppl):S16-25.

11. Chadha NK, Zhang L, Mendoza-Sassi RA, Cesar JA. Using nasal steroids to treat nasal obstruction caused by adenoid hypertrophy: does it work?. J Otolaryngol Head Neck Surg. 2009;140(2):139-47.

12. Rout MR, Mohanty D, Vijaylaxmi Y, Bobba K, Metta C. Adenoid hypertrophy in adults: a case series. Indian J Otolaryngol Head Neck Surg. 2012;10(2):10-5.

13. Berluchi M, Salsi D, Valetti L, Parrinello G, Nicolai P. The role of mometasone furoate aqueous nasal spray in the treatment of adenoid hypertrophy in the pediatric age group: preliminary results of a prospective, randomized study. Pediatrics. 2007;119(6):e1392-7.

14. Cengel S, Akyol MU. The role of topical nasal steroids in the treatment of children with otitis media with effusion and/or adenoid hypertrophy. Int J Pediatr Otorhinolaryngol. 2006;70(4):639-45. 